\title{
Interlanguage of Error Analysis on Students Writing in Covid-19 Pandemic Era
}

\author{
Winda Siska Perwana Harahap \\ Universitas Negeri Padang \\ email:windasiskaharahap@gmail.com
}

\begin{abstract}
This study aims to investigate the interlanguage of error analysis production on students writing. In writing process, there are general problem that occur such error from the interlanguage. This problem certainly getting worse during this Covid -19 pandemic era where the students only have limited direct or face to face English learning for one hour per week. Interlanguage is language used by second or foreign language when prosess of learning the target language. Data collected through documentation technique. The sample was taken using purposive sampling technique. There were five students as the sample. The framework of interlanguage and error analysis was applied in the process of data analysis. The results of this study indicate that the interlanguage of the students is influenced by $78 \%$ of language transfer, $10.5 \%$ of transfer of training and $10.5 \%$ of overgeneralization.
\end{abstract}

Keywords: Interlanguage, error analysis, writing, Covid Pandemic

\section{Introduction}

This Covid- 19 era has disrupts all aspect of life such as health, economy, social and education. The learning process was hampered in early 2020. The Ministry of Education and Culture decided that all activities in education institution such as schooling and lectures should be carried out online from home. In practice, an online learning requires educators and students to interact and transfer knowledge online. However, not all the students can participate in this distance online learning. Many factors contribute to this limitation. Include limitation of tool and technology such as mobile phones, networking and others. Therefore, in 2021, the government began to change the learning system to Limited Face to face Learning in the Level 3 PPKM Area. In this system students are able to do direct learning or face to face learning by coming to school with limited lesson hours. According to a junior high teacher, the students in each grades level is only have one hour of each subject in a week. It is include English subject. Getting the goal of learning English has many obstacles, especially during this Covid-19 Pandemic.

Learning and mastering a foreign language for those who study languages in different setting is not an easy task to do. Learners are always faced with some complicated language problems in the process of learning a foreign language. In the case of English as a foreign language, the use of verbs, prepositions, and word classes is difficult for second language or foreign language to understand. When learners learn a second or foreign language, they tend to make mistake. Mistake basically is part of natural process of acquiring and learning a new language. The mistake occurs in the four of basic skill of English acquisition, such as speaking, listening, reading and writing.

Interlanguage promoted first by Selinker (1972) to attempt learning of a second language. The term interlanguage have also reflect by Corder (1982) to idiosyncratic dialect and transitional competence. These terms represent two different perceptions. First, interlanguage related to the learners' structure system at each level of its progress. Second, it related to the set of interrelated systems referred to as the 
learners' built-in-syllabus. For example, the interlanguage continuum. Based on Selinker's perception about interlanguage, Wang \& Fan (2020) conclude that Interlanguage is a language system between native language and target language and used by L2 learner. This system is different from learners' native language and target language in the aspect of phonetics, vocabulary, grammar, culture and communication function. And it is a motive language system approaching to correct target language in the process of study and progress.(Wang \& Fan, 2020)

Selinker in Ellis (1985) conceptualized that there are three principal features of interlanguage. First, Interlanguage is Permeable. This means that the learner are ready to amendment the rules that make up their knowledge. In this case, the system of rules is not always fixed but is available to new rules.Second, Interlanguage is Dynamic. This means that second language learners are ceaselessly changing. This is become instability or keep fickle. This dynamic system gradually improves the temporal system to hold new hypotheses about the target language system.Third, Interlanguage is Systematic. It has its own rules. The language analyzed based on systematic rules. In the same way as native speakers, student performance is based on the existing system of rules.

There are five central process related to interlanguage based on what Selinker in Ellis (1985) conceptualized. First is Language Transfer. Rule and subsystems which occur in interlanguage performances are result of native language. For example, it borrowing pattern from mother tongue. The second is transfer of Training. Rules and subsystems are the result of identifiable items in the training procedure. For example, errors in processing result from misleading and generalized information provided by textbook and language teachers. (Kusumawardhani, 2017) It means applying the subject material from text book into communication. The third is Overgeneralization. If the outcomes are the result of applying the target language rules and semantic features that are not appropriate. (Creo, 1990). It because of the learners tend to over generalize the rule in the target language to reduce to simpler levels. (Kusumawardhani, 2017). It refers to extending pattern from the target language.The fourth is Strategies of second language learning. This is concerning the distinct strategies that influence the structure of sentence surface. This process is exhibited by the learner's proclivity to simplify the target language.(Kusumawardhani, 2017). The fifth is Strategies of second language communication. It refers to strategy that can be categorized by preventing grammatical forms such as article, plural, past tenses.(Kusumawardhani, 2017). It is also expressing meaning using words and grammar.

Interlanguage study is part of the study of language or linguistic which has a purely theoretical value regardless of its primary relevance to language teaching. One of the common theories concerning to the problem of second language learning is behaviouristic which infer that learning is mostly a statement of acquiring a new set of language habits.(Corder, 1982). Due to the interlanguage improvement in EFL teaching, errors are often made occurs in both spoken and written texts. Therefore, error occurs because of the mother tongue habits that exist in the new language. The term interlanguage is believed to be a language that is combine between first language and the target language. This case can be reviewed because of the many error that can be ascribed to the transfer process.(Corder, 1982).

Richard in Kusumawardhani (2017) describe errors as "The use of Linguistic item in a way which a fluent or native speaker of language regards as showing faulty or incomplete action". Dulay in Andrian (2015) defines "error as the flawed side of the learners' speech or writing". Brown in Andrian (2015) stated that "errors are a noticeable deviation from the adult grammar of an native speaker, reflecting the interlanguage competence of the learners."

Surface structure of error analysis as conceptualized by Dulay in (Agustina \& Junining, n.d.) are consist of four type. First, omission which is the type of error because of wrong placement of morphemes. Second, addition which is an error that refers to the presence of item that must not appear in utterance. Third, misformation which is characterized by using of wrong form of morpheme or structure. Fourth, misordering, which characterized by the incorrect placement of a morpheme in an utterance. 
Writing is one of the skills that should be master by learners in mastering English. Harmer in (Fitriani et al., 2019) stated that "writing is a complex cognitive process that sustained intellectual effort over a considerable period". Writing is associated with many types of writing, one of which is writing text. Text consists of several types called genres. There are also the types of genre text. One of that is descriptive text. Winch in (Siregar \& Dongoran, 2020) define that descriptive text as a text that describe about particular thing such as a scene, an animal, person or something happen in nature. In descriptive text writing process, student may face many difficulties so that they will produce some error in it. With the existence of several problems related to writing students who exist during the covid pandemic era like today which greatly reduces the hours of English lessons to one hour per week, it is possible to be one of the causes of this research being made. This study aims to analyze the Interlanguage of error analysis on students writing in covid-19 pandemic era.

\section{Methods}

Descriptive qualitative is used to analyze this research result. The data was taken from students' writing task sheet which was obtained from the teacher. The students' writing test is about writing descriptive text. The sample was taken using purposive sampling techniques, where the researcher chose only five junior high students. In analyzing the data, the researcher did a non statistical analysis. The result presented in a form of percentage of interlanguage. The researcher used five central process of interlanguage which conceptualized by Selinker.

\section{Result and Discussion}

This research data was analyzed and referred it into five central process of interlanguage by Selinker.

1. Language Transfer

The development of the student which learns English as foreign language may be interfered by their mother tongue. For example they might borrow pattern for mother tongue.

Table 1. Students error in writing descriptive text refers to language transfer

\begin{tabular}{|c|c|c|c|c|}
\hline Initial & $\begin{array}{l}\text { Influence of the } \\
\text { mother tongue }\end{array}$ & $\begin{array}{c}\text { Trancript of } \\
\text { students } \\
\text { speaking }\end{array}$ & Errors & Correction \\
\hline \multirow[t]{3}{*}{$\mathrm{RV}$} & $\begin{array}{l}\text { Using Indonesian } \\
\text { syntactic pattern } \\
\text { in translation } \\
\text { (Misordering) }\end{array}$ & $\begin{array}{l}\text { Favourite my } \\
\text { friend is fried } \\
\text { rice }\end{array}$ & $\begin{array}{l}\text { - Favourite my } \\
\text { friend is fried } \\
\text { rice } \\
\text { - Makanan } \\
\text { kesukaan teman } \\
\text { ku adalah nasi } \\
\text { goreng }\end{array}$ & 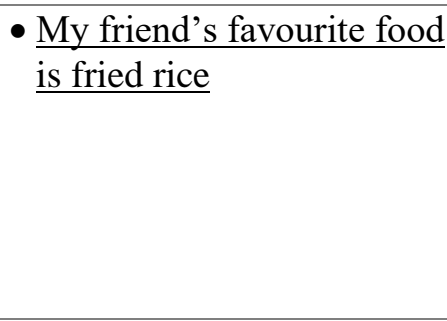 \\
\hline & Omission & My friend good & $\begin{array}{l}\text { - My friend good } \\
\text { - Temanku baik }\end{array}$ & - My friend is kind \\
\hline & Misformation & My friend good & $\begin{array}{l}\text { - My friend good } \\
\text { - } \quad \text { temanku baik }\end{array}$ & - My Teacher is kind \\
\hline WA & Misordering & $\begin{array}{l}\text { I and Sultan like } \\
\text { together play } \\
\text { football. }\end{array}$ & $\begin{array}{l}\text { - } \underline{\text { I and Sultan like }} \\
\frac{\text { together play }}{\text { football }} \\
\text { - Saya dan Sultan } \\
\text { suka bermain } \\
\text { bola bersama }\end{array}$ & $\begin{array}{l}\text { - Sultan and I like } \\
\text { playing football } \\
\text { together }\end{array}$ \\
\hline
\end{tabular}




\begin{tabular}{|c|c|c|c|c|}
\hline & Omission & $\begin{array}{l}\text { Sultan go to } \\
\text { stadion with me }\end{array}$ & $\begin{array}{l}\text { - Sultan often go } \\
\text { to stadion with } \\
\text { me } \\
\text { - Sultan sering } \\
\text { pergi ke stadion } \\
\text { bersamaku }\end{array}$ & $\begin{array}{l}\text { - Sultan often goes to } \\
\text { stadium with me }\end{array}$ \\
\hline & Misformation & Her hair is black & 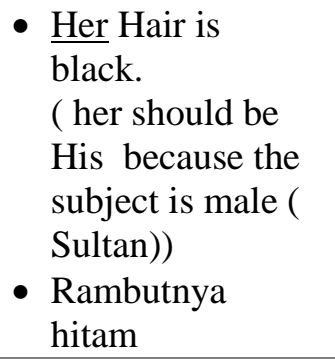 & - His hair is black \\
\hline \multirow[t]{3}{*}{ RAN } & Misordering & $\begin{array}{l}\text { Salsa likes } \\
\text { teacher } \\
\text { Matematica }\end{array}$ & $\begin{array}{l}\text { - Salsa likes } \\
\text { teacher } \\
\text { Matematica she } \\
\text { - Dia suka guru } \\
\text { matematikanya }\end{array}$ & $\begin{array}{l}\text { - Salsa likes her math } \\
\text { teacher }\end{array}$ \\
\hline & Omission & $\begin{array}{l}\text { Salsa is student } \\
\text { SMP } 6 .\end{array}$ & $\begin{array}{l}\text { - Salsa is student - } \\
\text {-- SMP } 6 \\
\text { - Salsa adalah } \\
\text { murid SMP } 6\end{array}$ & $\begin{array}{l}\text { - Salsa is a student of } \\
\text { SMP } 6\end{array}$ \\
\hline & Misformation & She is face cute & $\begin{array}{l}\text { - She is face cute } \\
\text { - Wajahnya imut }\end{array}$ & - His face is cute \\
\hline \multirow[t]{3}{*}{ FL } & Misordering & $\begin{array}{l}\text { Aris wear often } \\
\text { clock black }\end{array}$ & $\begin{array}{l}\text { - Aris wear often } \\
\text { clock color black } \\
\text { - Aris sering pakai } \\
\text { jam tangan } \\
\text { warna hitam }\end{array}$ & $\begin{array}{l}\text { - Aris often wears black } \\
\text { clock }\end{array}$ \\
\hline & Omission & He tall & $\begin{array}{l}\text { - He tall } \\
\text { - Dia tinggi }\end{array}$ & - He is tall \\
\hline & Misformation & $\mathrm{He}$ is mole & $\begin{array}{l}\text { - He is mole } \\
\text { - Dia punya tai } \\
\text { lalat }\end{array}$ & - He has mole \\
\hline \multirow[t]{3}{*}{ US } & Misordering & $\begin{array}{l}\text { Voice Putri is } \\
\text { very good }\end{array}$ & $\begin{array}{l}\text { - } \frac{\text { Voice Putri is }}{\text { very good }} \\
\text { - Suara putri } \\
\text { sangat bagus }\end{array}$ & $\begin{array}{l}\text { - Putri's voice is very } \\
\text { good }\end{array}$ \\
\hline & Omission & Putri like singing & $\begin{array}{l}\text { - Putri like singing } \\
\text { - Putri suka } \\
\text { bernyanyi }\end{array}$ & - $\quad$ Putri likes singing \\
\hline & Misformation & $\begin{array}{l}\text { My best friend } \\
\text { Putri life in } \\
\text { Tolang }\end{array}$ & $\begin{array}{l}\text { - My best friend } \\
\text { Putri life in } \\
\text { Tolang } \\
\text { - Temanku Putri }\end{array}$ & $\begin{array}{l}\text { - My best friend Putri } \\
\text { live at Tolang }\end{array}$ \\
\hline
\end{tabular}


The table shows that language transfer is very often used by students as an interlanguage process. All students selected as sample indicated that their interlanguage influence by their mother tongue or native language. The error indications shown were misordering, omission and misfromation. It was found that one error case each in misordering, omission, misformation for each of the five students.

2. Transfer of Training

The development of the student which learns English as foreign language may be influence by the subject material from textbook.

Table 2. Students' error in writing descriptive text refers to transfer of training

\begin{tabular}{|c|c|c|c|c|}
\hline Initial & $\begin{array}{l}\text { Influence of the } \\
\text { subject material } \\
\text { from text book }\end{array}$ & $\begin{array}{l}\text { Transcript of } \\
\text { students } \\
\text { speaking }\end{array}$ & Errors & Correction \\
\hline RV & $\begin{array}{l}\text { Using } \\
\text { grammatical rules } \\
\text { E.g. degree of } \\
\text { comparison }\end{array}$ & $\begin{array}{l}\text { My friend more } \\
\text { tall and more } \\
\text { beautiful }\end{array}$ & $\begin{array}{l}\text { - My friend more } \\
\text { tall and more } \\
\text { beautiful } \\
\text { - Temanku lebih } \\
\text { tinggi dan cantik }\end{array}$ & $\begin{array}{l}\text { - My friend is taller and } \\
\text { more beautiful than me }\end{array}$ \\
\hline US & $\begin{array}{l}\text { Using Expression } \\
\text { of happiness }\end{array}$ & $\begin{array}{l}\text { I'm so happy to } \\
\text { voice Putri }\end{array}$ & $\begin{array}{l}\text { - I'm so happy to } \\
\text { voice Putri } \\
\text { - Saya senang } \\
\text { mendengarkan } \\
\text { suara Putri }\end{array}$ & $\begin{array}{l}\text { - I enjoy listening Putri's } \\
\text { voice }\end{array}$ \\
\hline
\end{tabular}

The table shows that transfer of training is used by two students as an interlanguage process. Since transfer of training is interlanguage process which student is influenced by the subject material from textbook, one student used grammatical rule such as degree of comparison, but there still an error found. One other student used expression of happiness which actually already learnt from the textbook.

3. Overgeneralization

The interlanguage use by students tend over generalize the rule in the target language.

Table 3. Students' error in writing descriptive text refers to overgeneralization

\begin{tabular}{|c|c|c|c|c|}
\hline Initial & $\begin{array}{l}\text { Influence of the } \\
\text { extending } \\
\text { pattern of the } \\
\text { target language }\end{array}$ & $\begin{array}{l}\text { Transcript of } \\
\text { students } \\
\text { speaking }\end{array}$ & Errors & Correction \\
\hline $\mathrm{RV}$ & $\begin{array}{l}\text { Using two } \\
\text { repetition of } \\
\text { expression and } \\
\text { adding 's' where } \\
\text { it should not be } \\
\text { ( addition) }\end{array}$ & $\begin{array}{l}\text { I like my friends } \\
\text { Zakia, she is } \\
\text { smart and } \\
\text { cleaver. She is } \\
\text { diligent and } \\
\text { often not lazy.. }\end{array}$ & $\begin{array}{l}\text { - I like my friends } \\
\text { Zakia, she is } \\
\text { smart and } \\
\text { cleaver. She is } \\
\text { diligent and often } \\
\text { not lazy.. } \\
\text { - Aku suka } \\
\text { temanku Zakia, }\end{array}$ & $\begin{array}{l}\text { I like my friend Zakia, she } \\
\text { is smart and diligent. }\end{array}$ \\
\hline
\end{tabular}


DOI: https://doi.org/10.24036/icolp.v1i1.46

\begin{tabular}{|c|c|c|c|c|}
\hline & & & $\begin{array}{l}\text { dia pintar. Dia } \\
\text { rajin }\end{array}$ & \\
\hline WA & Addition & $\begin{array}{l}\text { Sultan is doesn't } \\
\text { like English } \\
\text { lesson }\end{array}$ & $\begin{array}{l}\text { - Sultan is doesn't } \\
\text { like English } \\
\text { lesson } \\
\text { - Sultan tidak suka } \\
\text { pelajaran bahasa } \\
\text { Inggris }\end{array}$ & $\begin{array}{l}\text { - Sultan doesn't like English } \\
\text { lesson }\end{array}$ \\
\hline
\end{tabular}

The table shows that overgeneralization is used by two students and as an interlanguage process. Overgeneralization which means influenced by extending pattern of target language, have used by two students. One student used repetition and addition 's'. One other student used addition of auxiliary verb which is actually have used in the same sentence but different form.

In brief, from the total number of cases, it is indicated that the language transfer used by students is about $78 \%$. There are only found two cases indicated, about $10.5 \%$ of transfer of training is used by students. Likewise the use of overgeneralization which only used about $10,5 \%$. This finding is in line with Rohmana \& Jianggimahastu (2019) who found that the difficulties of students in that which usually often occurs is the interference between internal languages translation of the structure of the first language. This finding is similar to what was found in this study, namely language transfer. This finding is also supported by the findings from Puspita Puspita (2019) which concludes that students' Interlanguage is influenced by the occurrence of errors in terms of grammatical structure accuracy which in this case relates to being considered correct in the L1 structure which is considered incorrect in TL. So this is considered the same as language transfer from the findings of this study.

\section{Conclusion}

In this Covid 19 pandemic era, where the students only have limited direct or face to face learning for one hour per week, students' English mastery is increasingly problematic. Interlanguage and errors are problem that students face. In this research conducted by testing the writing skill of eight grade junior high students, it was found that there were indications of the use of interlanguage by students. This interlanguage related to the errors that occur in students' process of mastering English. There are 78\% of language transfers used by students as their interlanguage process. $10.5 \%$ indicated for transfer of training. Likewise with overgeneralization which shows that $10.5 \%$ of students use it as an interlanguage process. While, the other two processes such as conceptualized by Selinker called second language learning strategies and second language communication strategies were not found in the students' interlanguage processes in their writing.

The implication is that students will still find it difficult to produce texts as long as their knowledge of grammar is still lacking. Likewise with the problem of the lack of students learning English lessons which are only one hour per week due to covid 19. To overcome this problem, a good understanding of grammar and language transfer can help them improve their writing skills. In addition teachers should emphasize their teaching of students' writing difficulties that have been observed. This study concludes that teachers should teach and focus on correct use of verbs and also emphasize on grammatical meaning. Teachers must also always motivate students to be able to do independent study at home and outside of school considering the lack of language lessons currently available.

\section{References}

Agustina, V. \& Junining, E. (n.d.). Error analysis in the travel writing made by the students of English Study Program. Brawijaya University of Malang, Indonesia, 1-28.

Language Learning Innovation in Pandemic Covid-19 Era 
Andrian. (2015). An error analysis of EFL students' english writing. English Education Journal, 6(4), 511-523.

Corder, S. P. (1982). Error analysis and interlanguage. UK: Oxford University Press.

Creo, D. P. (1990). The Process of Fossilization in Interlanguage.

Ellis, R. (1985). Undertanding second language acquisition. UK: Oxford University Press.

Fitriani, F., Nur, R. H., Bustamin, B., Ali, S. M., \& Nurisman, N. (2019). Improving students' descriptive text writing by using writing in the here and now strategy at the tenth grade students of vocational high school. International Journal for Educational and Vocational Studies, 1(6), 632-636.

Kusumawardhani, P. (2017). The Analysis of Errors of Omission in English Narrative Composition Made by EFL Students. JELE (Journal of English Language and Education), 3(2), 84.

Puspita, D. (2019). Error analysis on learners' interlanguage and intralanguage: A case study of two adolescent students. Teknosastik, 17(2).

Rohmana, W. I. M., \& Jianggimahastu, P. (2019). Error Analysis of Students' Recount Text Writing Junior High School Student. JETLe (Journal of English Language Teaching and Learning), 1(1).

Selinker, L. (1972). Interlanguage. IRAL: International Review of Applied Linguistics in Language Teaching, 3(10), 209-231.

Siregar, S. R. \& Dongoran, N. (2020). Students' ability in writing descriptive text Institut Agama Islam Negeri (IAIN) Padangsidimpuan. English Education: English Journal for Teaching and Learning, 08(01), 88-90.

Wang, X., \& Fan, L. (2020). An analysis of interlanguage features and English learning. Journal of Higher Education Research, 1(1), 1-7. 